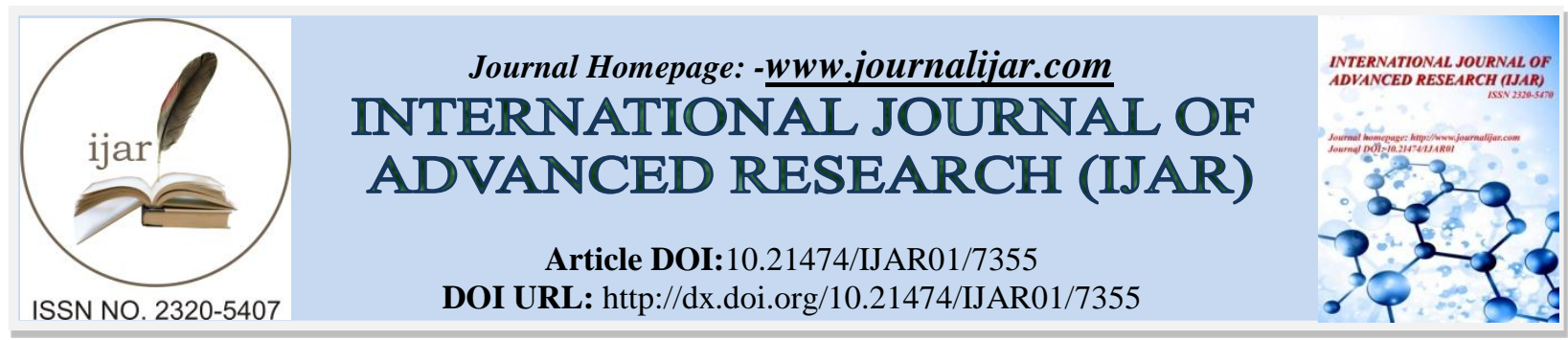

RESEARCH ARTICLE

\title{
DEVELOPMENT OF REAL QUESTING LEARNING MODEL FOR BIOLOGY LEARNING IN SENIOR HIGH SCHOOL.
}

\author{
Joko Slamet $^{1.2}$, Wachju Subchan ${ }^{3}$ and Jekti Prihatin ${ }^{3}$. \\ 1. Postgraduate Student of Science Education Program, University of Jember, Indonesia. \\ 2. Biology Teacher on Senior High School of Panarukan, Situbondo, Indonesia. \\ 3. Postgraduate Lecture of Science Education Program, University of Jember, Indonesia.
}

\section{Manuscript Info}

Manuscript History

Received: 05 May 2018

Final Accepted: 07 June 2018

Published: July 2018

Keywords:-

Real questing, biology, learning.

\begin{abstract}
Learning on Curriculum 2013 is expected to enrich students' learning experiences through a scientific approach. One of the activities of scientific learning approach questioning. Questioning activities are expected to arise from students. But the activity of asking students in biology learning is still low. Therefore, The REAL QUESTING learning model is developed to improve students'questioning skills. Product quality criteria for model development are validity, practicality, and effectiveness. The purpose of this research is to develop a valid, practical, and effective REAL QUESTING learning model. The research method used in this research is the research method of development of Borg and Gall. Based on the results of data analysis can be concluded that the development of REAL QUESTING learning model meets the three aspects of product quality criteria those are the validity 88.40 (very valid), practicality 81.40 (highly implemented) and, the effectiveness of the student,s questioning skill 77.50 (good), student learning with N-Gain analysis 0.75 (high), and student response 89.14 (strongly agreed) for use in main field testing.
\end{abstract}

Copy Right, IJAR, 2018, All rights reserved.

\section{Introduction:-}

Students at the secondary education level not yet subject to education or less actively involved in the learning process (Ministry of Education and Culture, 2015: 15). The condition like this shows that the process of teaching and learning is dominated by the teacher (Boleng and Corebima, 2014: 37 ). If the process of teaching and learning is teacher dominated, instruction becomes boring for students resulting in their minds wondering and may miss important facts (Otukile dan Mpho, 2018). The learning process that is dominated by teachers makes students unable to express themselves and direct their own learning. ( Tabulawa, 2006)

The expected learning process in the 2013 Curriculum is learning that enriches students' learning experiences using a scientific approach to develop to develop student's skills The scientific approach of the 2013 Curriculum consists of observing, asking the question, gathering information, associating, communicating (Suyanto, 2017). Activity inquiring on scientific approach is an activity involving students (Hynes and Berry: 2014), but the student asking activities in learning is relatively low (Slamet, 2016). This shows the creativity and participation of students in learning are still not optimal. Creativity and student participation in learning can be grown through innovative

Corresponding Author:-Joko Slamet.

Address:-Postgraduate Student of Science Education Program, University of Jember, 
learning models (Shoimin, 2014: 18). Therefore developed REAL QUESTING learning model designed to be able to provide learning experiences to ask students in the learning process so as to improve students' questioning skills.

The purpose of this research is to test product quality of REAL QUESTING learning model which includes validity, practicality, and effectiveness. After knowing the quality of products expected to produce REAL QUESTING learning model is feasible and can be applied in wider learning.

\section{Method:-}

Method applied in the development of REAL QUESTING learning model is Research and Development. Educational development research is a process used to develop and validate educational products (Borg and Gall, 1989).

Nieveen (1999) states that the quality of education development products has an important role in education. Furthermore, Nieveen (2010) stated that the quality of product development result refers to three criteria, namely validity, practicality, and effectiveness.

The development procedure of learning model REAL QUESTING refers to the design of Borg and Gall development model. This paper is only discussed until the small test scope is the fifth step that includes: (1) research and information collecting, (2) planning, (3) develop a preliminary form of product, (4) preliminary field testing, (5) main product revision

\section{Data Collection Techniques:-}

Collection techniques used in the development of learning models REAL QUESTING tailored to the criteria of product quality development of learning models are validity, practicality, and effectiveness. The compatibility of data collection techniques with these criteria is listed in Table 1.

Table 1:-Data Collection Techniques

\begin{tabular}{|l|l|l|l|}
\hline \multicolumn{1}{|c|}{ Criteria } & \multicolumn{1}{|c|}{ Data required } & Data collectiontechniques & \multicolumn{1}{c|}{ Instrument } \\
\hline Validity & $\begin{array}{l}\text { Product quality of REAL } \\
\text { QUESTING learning model }\end{array}$ & Validation Process & $\begin{array}{l}\text { validation sheet of REAL } \\
\text { QUESTING }\end{array}$ \\
\hline Practicality & $\begin{array}{l}\text { Implementation of REAL } \\
\text { QUESTING learning model }\end{array}$ & Observation & $\begin{array}{l}\text { observation sheet of REAL } \\
\text { QUESTING }\end{array}$ \\
\hline Effectiveness & Student asking skills & Observation & $\begin{array}{l}\text { observation sheet of a student } \\
\text { asking skills }\end{array}$ \\
\cline { 2 - 4 } & Learning outcomes & Test & Problem test \\
\cline { 2 - 4 } & Student response & Questionnaire & $\begin{array}{l}\text { Questionnaire of student } \\
\text { responses }\end{array}$ \\
\hline
\end{tabular}

\section{Data Analysis Techniques:-}

Data obtained analyzed descriptively to answer product quality learning model REAL QUESTING namely:

\section{Validity:-}

Validity obtained from instrument validation and validation of learning model. The data obtained are descriptive and quantitative. Descriptive data is obtained from validator suggestions or comments. Quantitative data is obtained from the assessment aspect using check-list $(\sqrt{ })$ with the following criteria.

(1) Score 4, if the validator provides excellent judgment.

(2) Score 3, if the validator provides good judgment.

(3) Score 2, if the validator gives a poor rating.

(4) Score 1 , if the validator gives a bad rating.

Further data validation results are analyzed using percentage data analysis techniques.

$$
\mathrm{V}=\frac{\mathrm{TSe}}{\mathrm{TSh}} \mathrm{x} 100 \%
$$




\section{Description:-}
$\mathrm{V}=$ Validity
$\mathrm{TSe} \quad=$ Total empirical score obtained
TSh $\quad=$ Total maximum score (Akbar, 2015: 82)

The percentage data obtained from the above formula is converted into qualitative descriptive data referring to the validity criteria as shown in Table 2 .

Table 2:-Criteria of REAL QUESTING Learning Model

\begin{tabular}{|c|c|l|}
\hline $81.25 \leq \mathrm{x} \leq 100$ & Very Valid & Product ready to be utilized in the real field for learning activity \\
\hline $62.50 \leq \mathrm{x}<81.25$ & Valid & $\begin{array}{l}\text { The product can be continued by adding something less, make certain } \\
\text { considerations, the addition is not too large and not basic }\end{array}$ \\
\hline $43.75 \leq \mathrm{x}<62.50$ & Less Valid & Revise by re-examining carefully and looking for weakness \\
\hline $25.00 \leq \mathrm{x}<43.75$ & Not valid & Revise large and basic about the content of the product \\
\hline
\end{tabular}

(Akbar, 2015: 78)

\section{Practicality:-}

To know the practicality of the learning model required data implementation REAL QUESTING learning model. Criteria of The Feasibility Learning Model are listed in Table 3.

Table 3:-Criteria of The Feasibility Learning Model

\begin{tabular}{|c|l|}
\hline Model $(\%)$ & \multicolumn{1}{|c|}{ Category } \\
\hline $81.25 \leq \mathrm{x} \leq 100$ & Very accomplished \\
\hline $62.50 \leq \mathrm{x}<81.25$ & Implemented \\
\hline $43.75 \leq \mathrm{x}<62.50$ & Less performed \\
\hline $25.00 \leq \mathrm{x}<43.75$ & Not executed \\
\hline
\end{tabular}

(Akbar, 2015: 78)

\section{Effectiveness:-}

To know the effectiveness of the learning model required data about students' questioning skills, learning outcomes, and student responses.

\section{Student's Questioning Skills:-}

The data obtained were analyzed descriptively using percentage (\%), is the score obtained by the students divided by the total score multiplied by $100 \%$.

$$
\text { Student's Questioning score }=\frac{\text { score gained by the student }}{\max \operatorname{score}(20)}
$$

The determination of the Student questioning skills criteria refers to Table 4.

Table 4:-Student questioning skills Category

\begin{tabular}{|c|c|}
\hline Questioning Skill $(\%)$ & Category \\
\hline $81.25 \leq \mathrm{x} \leq 100$ & Very Good \\
\hline $62.50 \leq \mathrm{x}<81.25$ & Good \\
\hline $43.75 \leq \mathrm{x}<62.50$ & Less good \\
\hline $25.00 \leq \mathrm{x}<43.75$ & Not good \\
\hline
\end{tabular}

(Akbar, 2015)

\section{Learning Outcomes:-}

The improved learning outcomes were analyzed based on the normalized gain average score $(\mathrm{g})$ using the following equation.

$$
(g)=\frac{(\% \text { post })-(\% \text { pre })}{100-(\% \text { pre })}
$$




\section{Description:-}

(g) = average score of normalized gain

$(\%$ post $)=$ average percentage of post-test score gained by students

$(\%$ pre $)=$ average percentage of pretest score gained by students (Hake, 2007).

Category determination as listed in Table 5.

Table 5:-N-Gain Category

\begin{tabular}{|c|c|}
\hline Score Normalized Gain & Category \\
\hline $0.70 \leq$ Normalized gain & Height \\
\hline $0.3 \leq$ Normalized gain<0.70 & Medium \\
\hline Normalized gain<0.3 & Low \\
\hline
\end{tabular}

(Hake, 2007)

\section{Student response to The REAL QUESTING learning model:-}

Student response indicator to REAL QUESTING learning model consists of three indicators: a) Interest on learning, b) Usefulness to follow learning, c) Interest following learning for the next chapter. Student response is measured using a student response observation instrument consisting of 11 points statement with score range between 1 up to 4. Description for each scores figures as follows: a) $1=$ disagree b) 2 = less agree c) 3 = agree, and d) $4=$ strongly agree.

The data obtained were analyzed descriptively using percentage (\%), is the score obtained divided by the total score multiplied by $100 \%$. the criteria of student response to the learning model are listed in Table 6.

Table 6:-Criteria of student response to the learning model

\begin{tabular}{|c|l|}
\hline$(\%)$ & \multicolumn{1}{|c|}{ Category } \\
\hline $81.25 \leq \mathrm{x} \leq 100$ & Strongly agree \\
\hline $62.50 \leq \mathrm{x}<81.25$ & Agree \\
\hline $43.75 \leq \mathrm{x}<62,50$ & Less agreed \\
\hline $25.00 \leq \mathrm{x}<43.75$ & disagree \\
\hline
\end{tabular}

(Akbar, 2015: 78)

Results And Discussion:-

Results:-

Table 7:-Data Results Distribution Questionnaire

\begin{tabular}{|c|l|l|c|c|}
\hline NO & \multicolumn{1}{|c|}{ VARIABLE } & ANSWER & QUANTITY & \\
\hline \multirow{2}{*}{1} & $\begin{array}{l}\text { ask questions in the biology } \\
\text { learning process }\end{array}$ & Yes & 41 & 12.4 \\
\cline { 2 - 5 } & & Sometimes & 42 & 12.7 \\
\cline { 2 - 5 } & & No & 248 & 74.9 \\
\hline
\end{tabular}

Product Validation

Table 8:-Product Validation Results of Development of REAL QUESTING Learning Model

\begin{tabular}{|c|c|c|c|c|c|c|c|}
\hline \multirow[t]{2}{*}{ No } & \multirow[t]{2}{*}{ Variable } & \multirow[t]{2}{*}{ Indicator } & \multicolumn{3}{|c|}{ Validator Rating (V) } & \multirow{2}{*}{$\begin{array}{c}\text { Average } \\
(\%)\end{array}$} & \multirow{2}{*}{$\begin{array}{l}\text { Product } \\
\text { Validity }\end{array}$} \\
\hline & & & V1 & V2 & V3 & & \\
\hline \multirow[t]{5}{*}{1} & \multirow{5}{*}{$\begin{array}{l}\text { Model of REAL } \\
\text { QUESTING } \\
\text { Learning }\end{array}$} & a. Supporting Theory & 75.00 & 100.00 & 87.50 & 87.50 & \\
\hline & & b. Learning Model Structure & 78.95 & 92.11 & 98.68 & 89.91 & \\
\hline & & $\begin{array}{l}\text { c. Selection of Media / Learning } \\
\text { Resources }\end{array}$ & 75.00 & 100.00 & 100.00 & 91.67 & \\
\hline & & d. Feasibility of Language & 75.00 & 89.29 & 89.29 & 84.52 & \\
\hline & & \multicolumn{4}{|l|}{ Validation Average } & 88.40 & $\begin{array}{l}\text { Very } \\
\text { Valid }\end{array}$ \\
\hline
\end{tabular}

Preliminary field testing Result 
Table 9:-Results of Student Skills Assessment

\begin{tabular}{|c|c|c|c|}
\hline \multicolumn{4}{|c|}{ Value of Inquiring Skills } \\
\hline 1 st & 2nd & 3th & 4th \\
\hline 52.50 & 61.25 & 65.00 & 77.50 \\
\hline
\end{tabular}

Table 10:-Results Pre-test and Post-test

\begin{tabular}{|c|c|c|c|c|}
\hline Learning cycle. & Pre-test Score & Post- test score & N Gain & Criteria \\
\hline $1 \mathrm{st}$ & 25.00 & 76.67 & 0.69 & Medium \\
\hline $2 \mathrm{nd}$ & 35.00 & 83.67 & 0.75 & High \\
\hline
\end{tabular}

Table 11:-Student Response to Learning Model REAL QUESTING

\begin{tabular}{|c|c|}
\hline Average of Aspect Statement & Criteria \\
\hline 89.14 & Strongly Agree \\
\hline
\end{tabular}

Table 12:-The Feasibility of REAL QUESTING Learning Model

\begin{tabular}{|c|c|c|c|}
\hline No & Aspects & Average (\%) & Category \\
\hline I & Initial Activity & 86.98 & Very Implemented \\
\hline II & Core Activities & 88.98 & Very Implemented \\
\hline III & Final Event & 84.03 & Very Implemented \\
\hline \multicolumn{2}{|c|}{ Average } & 81.40 & Very Implemented \\
\hline
\end{tabular}

\section{Discussion:-}

The result of research and collecting information in Tables 7 shows that the number of students who ask questions in the last decade in biology learning is still relatively low at less than 15\%. The low activity of asking students occurs because of several things such as factors of ignorance, prestige, and not given a chance. Student inquiry activities are an integral part of meaningful learning and science as well as the heart of science learning (Chin and Osborne, 2008). Thus the necessary learning conditions that can improve student ask activities through the development of learning models. Corebima and Bahri in Hariyadi (2017) explain that the learning model related to questioning activities of students is RQA (Reading, Questioning, Answering), Think-pair-strategy reinforces students' communication skills (Raba, 2017). Santrock (2011: 349) states that by having social skills then students will be able to communicate effectively. Steedlyet.al (2008) states that the inability to ask is related to the lack of socializing. Therefore, both models become the reference in the development of REAL QUESTING learning model.

The product of learning model development REAL QUESTING. The described the background and purpose of learning model development, theory supporting learning model, learning model structure, learning model characteristic (supporting theory, syntactic, social system, reaction principle, support system, instructional impact and companion impact), and how to apply the REAL QUESTING learning model.

One of the model characteristics is the syntax. The syntax is the stages of activity of the model. There is four syntax of Real Questing learning model, these are: (a) Reorientation, This syntax based on Thorndike theory about the Law of readiness, students readiness in the study will encourage learning to be beneficial (Schunk, 2012: 75). If students are ready, they will build their skill (Matsumoto, 2017), (b) Questioning syntax based on constructivism theory. Vygotsky explains the importance of social factors in learning (Bozkurt, 2017). This stage also refers to an Individual cognitive constructivist theory by Piaget that children think and reason differently at each stage of their cognitive development (Vygotsky, 1997), The learning process must be appropriate to the cognitive development so that the learner passes in order to achieve such goals (Bolton and Hattie, 2017). Groupings of students in constructivism is one of the important elements to maximize students' learning ability (Vygotsky, 1997)., cognitive scaffolding needs to be provided to facilitate students in order to solve the problem (Smagorinsky, 2018). Pedagogy based on constructivism requires an interaction between teacher and learner that includes eliciting of prior knowledge, exploration, and reflection (Moeed, 2013); (c) Investigation syntax based on Bruner's discovery learning theory that learning is in accordance with the active search for knowledge by humans and by itself gives the best results (Brunner, 1966), Through the investigation the students are given more opportunities to think, develop, and investigate the exciting things that disturb their curiosity (Evans, 1987).; (d) The fourth is solving syntax based on constructivism theory is that students as problem solvers. The problem solver is unsure how to cross the gap and 
reach a successful solution at the outset, there are still some strategies which are viewed as more effective than others and could facilitate the solver's efforts (Gulacar et al.2013). Students must learn to seek a clear-cut solution (Evans, 1987)

Based on table 8 shows that mean of learning model indicator that supporting theory, model structure, media selection, and language validity equal to 88.40 . Referring to the product validity criteria as shown in Table 1 , the product has a very valid category. Referring to the product validity criteria of instructional devices as shown in Table 2, the product has a very valid category. This indicates that the product developed has fulfilled one of the criteria of validity or validity. Validity or validity means that the product developed has a validity of content and construct validity Content validity indicates that models are developed based on sufficient theory, while construct validity indicates that all components of the learning model are related to each other consistently (Nieveen 1999: 127). Thus the product is ready for use in the field for small group Test.

Preliminary field testing is small group test is an activity of testing the product of learning model to a small group of students consisting of 9 students representing 3 groups of knowledgeability that are low, medium, and high. Base on the data of Table 1 shows that the implementation of the learning model is 81.40 . Referring to Table 3 on the Criteria of the Implementation of Learning Model then the application of this model is in the very done category. This value indicates that the product development meets the criteria of practicality. Product development results, concluded practically if the practitioner states theoretically the product can be applied in the field and the level of product implementation including good category. (Nieven, 1999).

Implementation of the preliminary field testing is also to determine the effectiveness of the model through observation of student's questioning skills, the measurement of student learning outcomes by using pretest and posttest, and student responses. Table 11 shows that the mean value of student's questioning skills at the 1st meeting was 52.50 , the 2 nd meeting was 61.25 , the 3 rd meeting was 65.00 , the 4 th meeting was 77.50 which means that the student's questioning skills do not immediately become good, This is reasonable because the students still need the training to have the skills asked as expected. Vale (2013) states that the skills of asking students require practice, guidance and practice in an environmentally active environment of inquiring. Based on Table 12 and Table 13 it can be seen that the post-test score was higher than the pre-test score. and $\mathrm{N}$-gain score increase from 0.69 (medium) to 0.75 (high).This result suggested that the skills of the students have increased after treatment. It means that the model can improve student learning outcomes. Table 14 shows that student response to the learning model is 89.14 with the category strongly agree, It shows that students appreciate the REAL QUESTING learning model. This condition indicates that the REAL QUESTING learning model can increase the student's questioning skills, learning outcomes and getting a very good response, so the REAL QUESTING learning model meets the criteria of effectiveness. Nieeven,(1999) says that the effectiveness of the product seen from the level of student appreciation of the learning program and the desire of students to continue using the program. Effective products appear to be consistent between the objectives and the learning experience with the achievement of student learning outcomes. Main Product Revision

In this step, the improvement is based on the findings. In this case, the observer provides input in order to maximize the use of media including IT in learning activities.

\section{Conclusion:-}

Product development of learning model REAL QUESTING meets three product quality development that is validity, practicality, and effectiveness. Validity value is 88,40 with the criterion is very valid, practical value with the value of 81.40 with the criterion is very done, effectivity value to ask student skill is 77.50 with the good criterion, student learning result value (N-Gain) is 0.75 with the high criterion and student's response value is 89.14 with criteria strongly agree. This model deserves to be applied in a large group test. 


\section{References:-}

1. Akbar, S. 2015. Teaching and Learning Instrument. Bandung: Remaja Rosdakarya.

2. Boleng, D.T. dan A.D. Corebima. 2014. Cooperative learning models having the better potency to improve the social attitude of multiethnic senior high school students at Samarinda, Indonesia. Journal of Educational Research and Reviews. 2(3): 36-44.

3. Bolton, S. Dan S. Hattie. 2017. Cognitive and brain development: executive function, Piaget, and the prefrontal cortex. Archives of Psychology. 1(3): 1-36.

4. Brunner. J.S. 1966.Toward The Theory Of Instruction. Newyork: Norton

5. Borg, W.R. dan M.D. Gall. 1983. Educational Research: An Introduction Fourth Edition. New York: Longman.

6. Bozkurt, G. 2017. Social constructivism: does it succeed in reconciling individual cognition with social teaching and learning practices in mathematics? Journal of Education and Practice. 8(3):210-218.

7. Chin, C. Dan J. Osborne. 2008. Students' questions: a potential resource for teaching and learning science. Studies in Science Education, 44(1): 1-39,

8. Evans, J. 1987. Investigations, the state of the art. Mathematics in School 16(1): 27-30.

9. Gulacar, O. C.R. Browman D. A. Feakes. 2013. Observational investigation of student problem solving: The role and importance of habits Science Education International 2(2): 344-3600

10. Hake, R. 2007. Six Lessons From The Physics Education Reform Effort. Lat. American Journal of Physics.1(1), 2431.

11. Haryadi, S. A. D. Corebima, S. Zubaidah,.Ibrohim. 2017. The Comparison of the Question types in the RQA (Reading, Questioning, Answering) learning model and conventional learning model. International Journal of Humanities social sciences and education (IJHSE).4(7):1018

12. Hynes M.B and G. Berry. 2014. Reading an object: developing effective scientific inquiry using student questions. European Journal of Science and Mathematics Education. 2(2):87-97

13. Joyce, B., M. Weil, dan E. Calhoun. 2009. Models of Teaching. Eighth Edition. New Jersey: Pearson Education

14. Ministry of Education and Culture. 2015. Strategy and Planning of Indonesia Ministry of Eduction and Culture 2015-2019. Jakarta: Ministry of Education and Culture

15. Matsumoto, K. 2017. A review of Jerome Bruner's educational theory: its implications for studies in teaching and learning and active learning (secondary publication). Journal Of Nagoya Gakuin University; Social Sciences.53(4): $129-146$

16. Moeed, A. 2013. Science investigation that best supports student learning: Teachers' understanding of science investigation. International Journal of Environmental \& Science Education. 8:537-559

17. Nieveen, N. (1999). Prototyping to reach product quality. dalam J.V.D Akker et. al (Eds), Design approaches and tools in Education and Training. Dordrecht: Springer-Science-Business Media-Kluwer Academic Publisher.

18. Nieveen, N. 2010. Formative Evaluation in Educational Design Research. dalam Tjeer Plum and Nienke Nieeveen (Ed). An Introduction. to Educational Design Research. Netherlands in www.slo.nl/organisatie/international/ publications

19. Otukile dan M.Mpho. 2018. Teacher-centered dominated approaches: their implications for today's inclusive classrooms. International Journal of Psychology and Counselling. 10(2): 11-21.

20. Tabulawa R. 2006. International aid agencies, learner-centred pedagogy and political democratisation: A critique. Comparat. Educ. 39(11):7-26.

21. Raba.A.A A. 2017.The influence of think-pair-share (tips) on improving students' oral communication skills in EFL classrooms. Creative Education. 8:12-23

22. Santrock, J. W. 2011. Educational Psychology. New York: McGraw-Hill Companies

23. Schunk, D.H. 2012. Learning Theories: An Educational Perspective; Sixth Edition. Boston: Pearson Education.

24. Shaymin, A. 2014. 68 Innovation model Of Teaching on 2013 Curriculum3 Yogyakarta: Ar Ruzz Media.

25. Slamet, J. 2016. Learning Readiness and Interest in asking student capability in biological learning in senior high school. Proceedings of National Conference. Physics Department, University of Jember

26. Smagorinsky, P. 2018. Deconflating the ZPD and Instructional Scaffolding: Retranslating and Reconceiving The Zone Of Proximal Development As The Zone of Next Development. Learning, Culture and Social Interaction.16:7075

27. Steedly, K.M., A. Schwartz, M. Levin, S.D. Luke. 2008. Social skill and academic achievement. Evidence for Education. National Dissemination Center for Children with Disabilities.3(2).

28. Suyanto, S.A. 2017. Reflection On The Implementation Of A New Curriculum In Indonesia: A crucial problem on school readiness. AIP Conference Proceeding:100001-100008

29. Vale, R. D. 2013. The Value of Asking Questions. The American Society for Cell Biology. 24: 680-682.

30. Vygotsky, 1997. Thought and Language. Cambridge.London: The Mitt Press. 